\title{
Ashura in Italy: The Reshaping of Shi'a Rituals
}

\author{
Minoo Mirshahvalad
}

Department of Cultures, Politics and Society, The University of Turin, Lungo Dora Siena, 100, 10153 Torino TO, Italy; mmirshahvalad2@gmail.com

Received: 17 January 2019; Accepted: 13 March 2019; Published: 15 March 2019

\begin{abstract}
This essay explores the impacts of Italy's socio-religious tendencies on the Shi'a rituals of Muharram and Safar. Ethnography and semi-structured interviews were the main methods adopted for the performance of this research. The implications of commemorating the Karbala tragedy in Italy were studied from four viewpoints. This article demonstrates that the presence of Shi'as in Italy not only exerts an effect on the core meaning of these rituals, namely paying tribute to Husayn's courageous stand against injustice, but also on the structure of Shi'a communities in terms of gender relations and power hierarchy.
\end{abstract}

Keywords: Ashura; Italy; Shi'ism; adaptation; change

\section{Introduction}

Despite the social implications of the Shi'a rituals in the first two months of the Islamic calendar (Muharram and Șafar), no sociological study has ever been conducted on their practice in Italy. The handful of works that mention Shi'as in the Italian context either deal with other issues, such as Italians' conversion to Shi'ism, transnational Shi'a networks, the importance of the Iranian revolution and the Shi'as' strong ties with their countries of origin (Allievi 2003, pp. 60-66; Vanzan 2004) or do not exceed a very short listing of some Shi'a associations (Bombardieri 2011, pp. 199-201; Menegotto 2004, p. 20; Lano 2005, pp. 211-13; Coppi and Spreafico 2006, pp. 120-21; Introvigne and Zoccatelli 2006, pp. 476-77).

This article aims to reveal the Italy's impacts on the Shi'a ${ }^{1}$ Muharram and Șafar rituals. Moreover, it shows how different subjects undergo different levels of change in their relations with these rituals. To comprehend these issues, one should reckon with, on the one hand, the socio-religious peculiarities of Italy, and on the other, the meaning of Ashura for those who commemorate it.

Although this peninsula's first encounter with Shi'ism occurred as early as the tenth century, that episode was too insular and too short to have cemented in the public mind. In contemporary time, the appearance of the first Shi'a organisations in Italy can be traced back to the early 1990s in Trieste, Rome and Naples (Vanzan 2004, p. 2; Bombardieri 2011, pp. 199-201), but the number of these organisations continues to change; some of them are vanishing because of their organisers' emigration to other Italian cities or abroad and yet others commence their activities in response to Shi'a citizen exigencies. At the moment, Italy's Shi'as are mainly of Pakistani, Iranian, Afghan and Lebanese origin. Iraqis and converts from Italy, Latin America and Africa form a small percentage of this population. Although Pakistani associations are significantly dispersed in Italy, the main hub of Shi'a circles are sited in Lombardy, where job opportunities attract migrants, yet where a culture of procession and auto-flagellation, such as in southern Italy ${ }^{2}$, does not exist. Therefore, Shi'a

1 In this article, "Shi'a" are defined as followers of the greatest branch of Shi'ism, namely the Twelvers.

2 See for instance how rituals of Procida are similar to a Shi'a procession (Lanternari 1997, pp. 287-88). See also (Mazzacane 1985). 
rituals during these two months are hardly comprehensible to outsiders. The first externalisation of Shi'a mourning can probably be traced back to 2009, when Pakistanis in Brescia realised their first procession. After them, Shi'as in Turin, Carpi, Milan, Rome and Legnano found the courage to do the same. In a relatively hostile context for immigrants, in which they are deemed as permanent strangers (Guolo 2010, p. 37; Aluffi Beck-Peccoz 2004, p. 133), there is a small population of Shi'as ${ }^{3}$ that has recently found the courage to go public. To grasp the sociological importance of mourning for Husayn in the Italian diasporic environment, one needs to consider that, in Italy, the ceremonies of Muharram and Șafar - more effective than weekly gatherings of $d u^{\prime} a$ of Kumeyl and Tawassul—were the first social glues that satisfied the desire for community years before Shi'a circles became registered associations. The day of Ashura, in particular, is the only event that does not undergo the regime of "calendrical adjustment", which is the usual adaptation strategy of Islam in the West (Abusharaf 1998, p. 256). For instance, although Ashura coincided with Thursday in 2018, it did not stop thousands of Shi'as of differing nationalities and Italian cities from gathering in front of the Milan central station to partake in a procession that stretched from the Repubblica Square back to the station. Such respect has never been observed for other rituals, not even for Arba'in nor for events related to other Imams or the Prophet. Id al-Fitr, which concludes a sacred month and has international valence, is celebrated either early in the morning with prayer or on social media when it coincides with work days.

Given these considerations, it is crucial to see how Shi'as adapt this "cornerstone" of their identity (Chelkowski 2005, p. 119) to the cultural characteristics of a country like Italy, and what such an adaptation entails in terms of inter-ethnic and gender relations. The present research demonstrates this process through the strategies of negotiation and compromise adopted by various Shi'a groups in different Italian cities. Defined classically, acculturation entails behavioural shifts in groups of individuals with different cultures that come into continuous and first-hand contact (Redfield et al. 1936). This contact entails reciprocal influences between them (Sam 2006, p. 17). Here, this essay focuses only on the influence of Italy on Shi'as and their rituals rather than the other way around. In the process of acculturation, immigrants mould their rituals according to the new context, which implies an inevitable renunciation of some of their components (Park and Burgess 1970, p. 346). In this way, the unsustainable economic and social costs for the minority culture are sorted out in a process of "culture shedding" (Berry and Sam 1997, p. 298). Rappaport believed that the form of ritual is inseparable from its substance. The ritual form is not an ancillary to its content but the best way, or perhaps even the only way, to express that content. In other words, ritual is not a neutral medium capable of conveying any message (Rappaport 1999, pp. 30, 37-38). Therefore, the question is: if the form of the Muharram and Șafar rituals in Italy has changed, can one expect their content also to have changed?

The information reported here is an outcome of observations and interviews conducted during Muharram and Șafar in 2017 and 2018 (September, October, November) during mourning sessions and processions in Rome, Milan, Legnano, Brescia, Carpi, Varese, Pavia, Turin and Como. Aside from Ashura, whose processions took place on 1 October 2017 and 20 September 2018 in Milan, the Arba'in procession on 11 November 2017 and 28 October 2018 in Legnano and the Ali Aşghar procession on 16 September 2018 in Brescia were taken into consideration. Fifteen semi-structured interviews and many informal conversations were conducted with the presidents of Shi'a associations, as well as with participants who were mainly from Afghan, Lebanese, Pakistani and Iranian origins, alongside a few converted Italians. This information was integrated with ethnographic notes. The author joined the Who IS Husayn? campaign, being responsible for explaining Imam Husayn to outsiders in English and Italian. Such a role provided the unique opportunity to witness and register outsider reactions

3 Although it is impossible to know their exact number, it is estimated that around 1.5\% of Italy's Muslims are Shi'as (Sciiti in Italia 2012, p. 17). Therefore, we can imagine that in Italy this population is a little over one hundred thousand. 
to this reality. Moreover, being an active member of this campaign allowed for an observation of the measures adopted by Iranian students to engage with their Italian context.

\section{Four Italian Impacts on Shi'a Rituals}

\subsection{The Rise of Intra-Religious Debates}

The interconnected implications of different nationalities encountering one another are presented here with regards to the rituals' form and language. Allievi has rightly asserted that only in Europe can Muslims experience the real sense of umma (Allievi 2002, p. 25). Italian Shi'as are from different national backgrounds ${ }^{4}$. Although they are aware of the presence of their coreligionists in Italy, the only moment that offers them the opportunity to feel the otherness of their coreligionists occurs during the outdoor Karbala tragedy commemorations. In Italy, people with very different religious and political outlooks join the commemorative Muharram and Șafar rituals. Occasionally, Sunnis and non-Muslims give their contributions to Ashura-related initiatives by helping with translations, correcting pamphlets and handouts, and even participating in processions and chest-beatings. As an ecumenical moment that gathers thousands of Shi'as, Ashura prepares the terrain for cultural differences among nationalities to surface and be noticed. In Italy, only Pakistanis, Iranians, Lebanese and Afghans are numerous enough to create groups of mourners. Other nationalities, on the occasions of mourning, may join these groups. When Shi'as need to hold yearly public and great events, debates on how to organise them emerge. Questions arise on whether participants should interact with the host context, and which strategies should be adopted to express loyalty to Husayn's cause. Pakistanis and Iranians are the most numerous components of the procession. With an approximate but useful generalisation, one can consider their approach to the externalisation of their faith as two antithetical types. The first type, which can be called the verbal or conceptual externalisation of grief, emerged with a campaign. In 2014, an Iranian PhD student of the Polytechnic of Milan, referred to here as Javad, decided to launch a campaign that later was called Who IS Husayn?. In 2015, the streets of Milan witnessed this campaign's activities for the very first time. Since then, Iranian students in different European cities have annually distributed beautifully designed pamphlets in local languages, edited and printed in Iran, which explain who Imam Husayn is and what Ashura means. In Italy, this initiative has so far been held in Rome, Milan and Turin. These booklets are usually accompanied by water bottles that symbolize the thirst of Imam Husayn and his troop, or flowers used to moderate the moroseness of black shirts and the mourners' flags. The first page of this booklet starts with two phrases: "I am in battle against injustice. Will you join me?" On the second page, Husayn is compared to Jesus because of their corresponding mothers and apostles. In this booklet, there are no subtle hints to "Shi'ism" or "minor Islam", but it does discuss "true" Islam, whose representative is Imam Husayn. This perspective on Islam is presented as an alternative to Wahhabism, ISIS and the Taliban.

The similarities between Husayn and Jesus were not discovered in Italy, though the re-elaboration of these similarities was. In fact, the source of this pamphlet is a series of Murtada Muțahari's lectures (d.1979) published in a book entitled Hamase-yi Husayni (Husayn's Epic). In the third chapter of this book, dedicated to an examination of the similarities between Jesus and Husayn, Muțahari employed an emotional approach to the "epic" of Husayn that was fabricated by preachers to arouse emotions among followers. This mythopoetic approach provoked conceptual distortions originating from Christian theology. One of the issues against which Muțahari took a position was the "false" belief that the similarities between Husayn and Jesus rested in the salvation they had allegedly guaranteed to humanity. The Iranian cleric first underlined that Jesus was never killed, and second, that although Husayn was killed, it was not to save humanity. Instead, the similarities between them derived from

4 It is repeatedly underlined that Islam in Italy, as opposed to France, Germany and the U.K., is a multi-ethnic reality, and Shi'as are no exception to this trend. See in (Pin 2010, p. 9) the reasons for this multi-ethnicity. 
other aspects of their lives. Firstly, it stemmed from their mothers, who were both țahirah (immaculate), şaddiqah (righteous), batul (pious) and the interlocutors of angels, and secondly from the duration of their pregnancy, which seemed miraculous. Thirdly, both Husayn and Jesus were blessed and exuded barakah (beatitude). Fourthly, people celebrate both their birth and their alleged martyrdom. Lastly, before leaving this world, one could find both heroes in a historic moment of dramatic conversation with their apostles. Muțahari used this context to criticise Christians for the superstitions that they had incorporated into the narratives of Jesus' life, their superficial approach to it, and the hypocrisies of the Pope.

Clearly, in the booklet of this campaign, criticism and polemical instances are omitted in favour of the two nonpareils' similarities. Here, the important question is why, in Europe, should this face of Shi'ism be accentuated to the detriment of its folkloric face? What is the "problem" of nonverbal, performative and symbolic methods of mourning, and what is the advantage of the verbal and conceptual methods in Europe? One part of the answer can be found in what Javad and other Iranian students expressed. Javad maintained that the idea of this campaign had sprung to his mind once he had noticed certain "problems" with what was going on in Italian cities on the day of Ashura. Upon asking him what he meant by "problems", he answered: "Well, the biggest problem starts with Pakistanis, although the Iranians are not better off, but they are mainly Pakistanis. The point is that their way of expressing grief, even to me as a Shi'a who is familiar with this historic episode, seems a bit violent. They wear black [clothes] and they are not usually even very clean. Many times I have seen them on the street in a tank top. They have black flags with Arabic writings that make no sense to Italians. So, one could not understand what the difference was between the writings on the flags of ISIS and those of Ashura. Both flags were black and had Arabic lettering. In Rome, autochthonous people, like [ ... ], held mourning sessions in Italian, but when there are not natives, it is difficult to make the event comprehensible to Italians". Despite the significant effort of Iranian students, the campaign was not welcomed by all procession participants. Javad continued: "The groups that organise the parades are usually against our activity because they believe in what they do and in the method they have had for 10 or 15 years, and then they make fun of us. For example, the first year they called us florists, which we perceived as an insult. They think that on the day of Ashura one must cry and be sad, so, distributing flowers is not good on such a day, though, I think crying in Europe does not make any sense. Maybe in Iran the discourse is different, but here I think we need to do something else. Many groups, for example Iranians, consider our activity a kind of meddling in their work, while the Pakistanis of Milan criticise us for the distribution of flowers".

In Milan, differently from Turin and Rome where no procession took place, the campaign was held alongside the procession, provoking debates among Iranian students on whether to follow mourners or to choose another city area. An Iranian PhD student of economy at the Biccoca University disapproved of the concomitance of these two events. He said: "We were more interested in cultural activities. We had prepared some booklets on Imam Husayn. We liked to give people flowers, and these two activities did not correspond .... one could see that in one part of the street people were beating themselves, in the other, they were distributing flowers!". A student of the Polytechnic of Turin who had led the campaign in Turin expressed his reluctance to wear black colours: "We did not want to mourn. We just wanted to explain who Imam Husayn was and the fact that he entered the battlefield without having wanted it, but only to defend himself. In our situation we must think of each and every word that we use ... because [Italians] are afraid of war and as soon as we mention war they get frightened". Later, he added that their scope was to convey a message of friendship: "We wanted to introduce ourselves and say who we are by demonstrating that we are not at war with anyone ... this was our Imam who defended himself against oppression". Not all students, though, despised the traditional mourning methods. An Iranian girl believed that these two methods were not contradictory, but rather complementary. With mourners in mind, she claimed: "They have shur-e Husayni (passion for Husayn) and we have shu'ur-e Husayni (understanding of Husayn)". Emotional engagement was sometimes considered not only innocuous, but even helpful among Iranian students. For instance, an 
Iranian girl who attended a master's degree in biomedical engineering in Trento believed that, without this type of involvement, their campaign could have been mistaken for many others in Europe that advocate humanitarian causes and do not exceed giving dry information. The Pakistani director of the Jafaria Association of Legnano mentioned an understandable reason to support the public mourning as it is currently performed. He understood the necessity of performing rituals in Italian, but emphasised that "Italy is very far from what we see in Britain ${ }^{5}$. Here, there is still very little awareness of what Shi'ism is. So, for the time being, mourning should be done in this way in order to draw the attention of people before giving them information".

Aside from form, there was also the question of language. The use of Italian and English had its benefits that went beyond dialoguing with outsiders. A middle-aged Pakistani man who lived and worked as a factory engineer in Novara had noticed the uselessness of adopting Urdu and Punjabi for rituals since the new generations could not understand them. He said: "Our children have grown up in Italy and do not know our language. They are raised in another culture. For me as a parent in order to live with them, they must comprehend Ashura. This is why I prefer Italian. Now all children speak Italian. My son also grew up here and speaks Italian". Apart from the second generation, Pakistanis who come from regions other than Punjab sometimes were not able to understand the Punjabi spoken by the mourners originating almost entirely from this region of Pakistan. Clearly, language is a challenge to Shi'as who live outside their original context. The issue becomes more complex in their case than in the case of Sunnis who do not have a culture of mourning for saints, and whose tradition refrains from highly emotional involvement with historical events. As an example, during Muharram commemorations at the Imam Mahdi Centre of Rome, Italy's first and only autochthonous cleric would give melodic rhythm to his Italian prose to provide his otherwise monotonous narratives an intonation suitable for the mourners' chest beatings. The Roman centre, differently from the Imam Ali Centre of Milan and similarly to the Tohid Centre of Turin, hosts a multi-ethnic community, and hence Italian is always used as the lingua franca so as to include all participants. Nonetheless, the atmosphere at the Centre during those nights and the Italian nohahs (elegies) was dramatically different compared to the Arabic, Turkish, Persian and Punjabi elegies in terms of the emotional involvement of congregants. This issue could be either a consequence of the sense of nostalgia the audience felt during the traditional elegies, or because the Italian language does not quite feature the rhythm necessary to provoke similar emotional escalation ${ }^{6}$. To complete the monochromaticity of the rituals, the Roman centre had eventually found a way to free itself from the Pakistani congregants who had caused trouble with their vigorous methods of mourning ${ }^{7}$. The language issue was underlined by the treasurer of the Lebanese Como Assirat association as well. He stated that Arabic for elegies, apart from adults, was preferred even by their children who could not understand Arabic but liked the language of their parents for those occasions, whereas Italian was more requested for prose narratives. Earning thawab (otherworldly reward), which is the raison d'etre for mourning within traditional and folk Shi'ism, is possible only through emotionally loaded actions. Therefore, if obtaining thawab is the scope of mourning ${ }^{8}$, Shi'a rituals cannot renounce traditional languages for the time being. However, if outsider

5 In fact, Shi'as in the U.K. have so much support and facilities that Scharbrodt found inappropriate the Sachedina's expression of "minority within minority" for them. See (Sachedina 1991; Scharbrodt 2018).

6 The use of European languages in Shi'a rituals affects not only the message structure but also its content. See (Alibhai 2018, p. 22; Langer and Weineck 2017, p. 240).

7 I avoided the word "expulsion" even though I knew that a dispute between Pakistanis and the Italian converts (who govern the roman centre) had happened because of Pakistanis' method of mourning. The latter, during Muharram ceremonies of 2018, had rented a show room on the outskirts of Rome where they could take off their cloths and perform their highly emotional mourning in peace.

8 The Shi'a collections of Hadith contain many narratives attributed to the Prophet and Imams who strongly urged people to weep and hold mourning sessions for Imam Husayn that will be rewarded in the hereafter. Some of these important collections are Wassail al-Shi'a, al-Khişal of Shayk al-Şaduq, Kamel al-Ziyarah and Thawab al-A'mal. As English sources see (Ayoub 1978, pp. 142-47; Shirazi 2005, pp. 93-94). 
involvement is desired, the content of the message, its language, and the method of its transmission should undergo modifications.

Despite these observations, Iranian students, at least in Milan where the procession took place, were aware of how much their verbal and conceptual method of commemorating Husayn depended on the symbolic, theatrical and nonverbal action of their coreligionists; the same coreligionists who had involved passers-by and shopkeepers in front of the central train station of Milan. It became the very success that Iranian students were incapable of achieving only through a very familiar initiative to European people like leaflet distribution. Apart from the courage and bravery of Pakistanis lacking in other nationalities, Italian bureaucracy provided another reason for Iranians to depend on Milan's Pakistanis. Any outdoor initiative in Italian cities can occur only upon request from registered associations, requests which should be submitted to municipalities. As neither the Islamic Association of the Iranian students nor the Imam Ali Centre are registered associations, the students' campaign could only obtain permission from local authorities through the Imamiyah Welfare Organisation of Milan, which is a Pakistani association.

\subsection{Women Gain Voice}

The ayatollahs, who are the only authorities of current Shi'a law, have emanated, inter alia, a series of ordinances for worship places. In Italy, however, we have Shi'a halls that do not meet the standards established by ayatollahs for a mosque (e.g., form and position of toilets, the position of entrances, their accessibility to non-Muslims and their use for non-religious purposes), but they respect two important issues: sexual division and the women's veil. Both of these measures are adopted to hinder sexual desire and keep the place of worship immune to "impurity". These two elements also entail a series of other non-written laws that, despite the official voices about women's importance in the community, exclude them from roles that involve leadership, visibility, and access to higher levels of the power hierarchy. In Italy, one witnesses different regimes of gender apartheid: its softer version exists within the halls of Middle Eastern Shi'as, where there exists a certain osmosis between the gender space, the partition becoming virtual rather than architectural. Nevertheless, in most of the gatherings, women are entrusted with nothing more than supporting roles or as spectators of male heroism. They follow the rhythm and activities organised and headed by men. This tendency becomes more acute when it comes to Pakistanis, who observe a very rigid regime of sexual division and actively avoid sexual promiscuity even outside places of worship. According to the prevalent ayatollah opinion concerning collective prayer, men and women can even pray in the same place as long as a certain distance is maintained. However, regarding sexual division, Pakistanis observe a much stricter regime of separation than their Middle Eastern counterparts, despite being followers of the same maraji' (sources of emulation). Pakistani women, as passive followers of guidelines established by tradition, can have a portion of "serious" male activities only through closed-circuit televisions installed in their specific halls without having any opportunity to contribute to them.

The voicelessness of Pakistani women and their reduced agency compared to their Middle Eastern counterparts undergo a drastic change when it comes to the Muharram and Șafar rituals. An episode that occurred while waiting for the head of a Pakistani community for an interview can illustrate. My presence in front of the entrance of the men's hall had created embarrassment in the way that I was asked to go back to the women's room. Keeping episodes like this in mind, I attended the Ali Asghar julus (procession) in Brescia. The commemoration of the martyrdom of Imam Husayn's youngest son was held in a street near the train station of Brescia. Around 50 barefoot Pakistani women and girls covered in black garments were conducting a slow procession behind the male group, which was carrying a symbolic coffin of Imam Husayn. While a woman was chanting elegies loudly, others flung either one or two arms up into the air, and then brought them swiftly back to strike themselves sharply on the chest with either one hand after the other, or both at the same time. Witnessing this 
act was quite surprising, given women singing in the presence of non-mahrams ${ }^{9}$ had been absolutely prohibited by the ayatollahs. The very same behaviour was then observed in Milan and Legnano. Women had a notebook in their hands where they had collected some poems. Each of them sang a song in Punjabi, and then passed the notebook to the next woman. When the notebook was no longer available, they would appeal to their cell-phones. In the meantime, another woman was pushing the symbolic cradle of Ali Asghar, which was made of steel, decorated with green hangings, and put on the top of a trolley. Women who joined the procession would touch and rub their hands and face against the cradle and put fruit, money, sweets, baby clothes, and small flags on the cradle. They were following the men's group while alternatively pushing the trolley, chanting and beating their chests. They had no concern for the curious who had come out of windows and doors with their cell-phones to film and photograph them. Sometimes, in the case of old women ${ }^{10}$, even a loosely closed dupatta would drop over their necks without objection to their uncovered hair. Interestingly, females leading the ritual in this case were not limited to trained dhakirahs (female preachers) who occasionally give talks within female Pakistani circles. Among the women's group, whoever was so inclined could contribute to the elegies with or without competent Punjabi. It was a democratic way of leading the female julus. These rituals provided Pakistani women-who are usually excluded from public life in Italy-with an opportunity to show their talents. Conversely, Iranian girls who come to this country to pursue personal goals, namely attending university courses rather than accompanying their husbands, showed their competence through the use of Italian and English language and communication with outsiders during the aforementioned campaign. The Iranian diplomats' wives who had come to Bel Paese just to join their husbands without language proficiency limited themselves to traditional roles, essentially following the procession without any physical or emotional involvement.

In an Afghan community in Varese, something even more notable was observed. While accompanied by a man who had come to the train station of Varese to pick me up, I was told that they would have been pleased to hear some discourse regarding this research. It sounded strange to me, even though I had so far given different talks on this research project, but I could not understand how nor why my serious discourses could be suitable for a lamentation ceremony. It did not take me long to eventually discover the meaning of that suggestion.

There were around 100 Afghans, mainly Hazaras, who had rented a bar wherein they had hung a black curtain to create two separate spaces. I was conducted towards an entrance where the women had sat down on sofas around a small hall. A chant in a high soprano, which seemed to be of a young boy, mixed with the sound of many palms hitting chests from the other side of the curtain. Some minutes after the elegy finished, two women passed between the curtains and entered the female space. I presumed that they had been there to photograph or film the men. Such a division of labour was familiar, namely men in the centre of ritual who would show off and women who would record their heroism. A while later, two other women stood up, passed through the curtain and a new round of elegies started. It was only at that moment that I decided to overstep the curtain and see what was occurring in the other side of the hall. There was a tribune covered in a black flag with the red writing of Ya Husayn-e Mazlum behind which two women, with a microphone in their hands, were reciting elegies while men were beating their chests in response to their rhythm. Sometimes, between two sessions of elegy, a talk was given by a woman on Ashura and germane topics during which the men were silent and listening. This overturning of roles went in direct contrast to standing ayatollahs' expectation. This overturning of roles was incredible. No ayatollah could have imagined such a situation. After the ceremony, while being given a ride to the station by community members, a young

9 The term mahram corresponds to women's unmarriageable kin, e.g., father, brothers, grandfathers, uncles, sons, sons-in-law, etc. Given that a sexual relationship is forever forbidden with these relatives, women are not bound to observe the limitations present in front of non-mahrams.

10 Young women, instead of a dupatta, had black maqnahas: a piece of cloth sewn underneath the chain that covers the head and shoulders. They opted for a more restrict regime of hijab because their age had made them more vulnerable. 
Afghan man who had noticed my astonishment told me that the relevance offered to women was a strategy to introduce an alternative model to the Iranian Shi'ism (or perhaps to compensate what women had undergone during Taliban dominance). In both cases, whether to contrast the Iranian style of Shi'ism or to compensate for the deplorable image of Afghan women under the Taliban, Ashura had created this terrain in the context of migration.

In the Lebanese ceremonies in Como and Pavia, women either did not cover their hair inside the halls, or only covered it during mourning sessions. After weeping and chest-beating, they would remove their head-covers. Sexual apartheid among the Lebanese was permeable and flexible. Women did not observe barriers in their relationship with men, and, after mourning, groups of men and women with refreshments in their hands casually engaged in conversation with each other. Notwithstanding their modern outlook, these women were content to perform the traditional roles of preparing refreshments and weeping while male preachers were reciting the elegies and eulogies of Karbala heroes. The Lebanese public mourning was usually limited to indoor events held inside parishes and consisted of elegies and theatrical performances. However, when the Lebanese group in Pavia prepares passion plays, as opposed to the Iranian $t a^{\prime} z i y a h$, female roles are entrusted to women themselves instead of being recited by men.

\subsection{Gaining Character; a Means for Dialogue?}

Although Ashura and its ancillary events per se are not considered instruments for crafting identity, only on these occasions do Shi'as first discover themselves, and then those qualities of their migratory context that allow them to enter into dialogue with it. This self-discovery, which cannot occur without the challenges of migration ${ }^{11}$, facilitates the adaptation process. In other moments, both the host context, which does not care about or even understand the differences between the various voices of Islam, and Shi'as themselves, who prefer to present themselves as Muslims rather than Shi' $^{12}{ }^{12}$, conceal, forget or ignore this identity. Shi'a preachers in indoor events may dare to reveal their controversial positions ${ }^{13}$, whereas in events that include a wider audience, they renounce contentious subjects. Shi'a organisations have a timid presence in the Italian public arena. Sometimes, they are absent from initiatives that confer prestige and visibility to Islamic communities, both on the national level-such as during the crucial moment when 10 Islamic organisations signed the National Pact for an Italian Islam ${ }^{14}$ _and the local echelon, such as the Mosques Open Day held during Ramadan 2017 in Turin ${ }^{15}$. One may never find a Shi'a place of worship by searching online for "mosques" of a certain city or looking through the lists of Islamic umbrella organisations, such as the AIA (Associazione islamica delle alpi) or CAIL (Coordinamento associazione islamiche del Lazio). Most of them have neither websites nor traceable addresses, especially so if they do not have stable headquarters. Moreover, their locals are invisible to outsiders, to their neighbours, and sometimes even to Shi'as of other cities ${ }^{16}$.

11 If identity is considered a product of an action rather than a "natural" quality of human beings, then exchange and interaction with "others" become a fundamental catalyst for its creation. See (Mach 1993, p. 5).

12 This tendency is observed also in Norway. See (Bøe and Flaskerud 2017, p. 182).

13 For example, giving more importance to the pilgrimage to Karbala than to Mecca, cursing the House of Saud, and provoking emotional escalation for Fatima martyrised by Umar.

14 This agreement with the Italian government was concluded on 1 February 2017. In the booklet published by the Interior Ministry (p. 9), the Council for relations with Italian Islam emphasised that the representatives of various voices of Islam were invited to partake in this fundamental step towards institutionalising Islam in Italy. However, no Shi'a representative was present among the Islamic organisations. Find the booklet at http://www.interno.gov.it/it/sala-stampa/pubblicazioni/ patto-nazionale-islam-italiano.

15 It was an initiative organised by the municipality of Turin, and the only Shi'a centre in the city did not participate in its 2017 edition. See (Mirshahvalad 2018, pp. 118-19). In 2018, and only after some persuasion, this centre agreed to adhere to the initiative.

16 In my visits among Shi'a organisations, I always faced the surprise of my Shi'a interlocutors whenever mentioning the name of an organisation that I had found in other cities thanks to word of mouth or informal methods. The three Shi'a circles that have stable headquarters do not have visible signs for outsiders. Others can be traced only through the "right" contacts, meaning those who know where the gatherings take place, are willing to inform, and, more importantly, are authorised to 
The processions of the first two months of the Islamic calendar offer Shi'as a good reason to be accessible and to overcome timidity, anonymity and "civil inattention" within the settlement context. The public space becomes a stage upon which Shi'a immigrants receive the importance and attention they are usually not given. A Sunni association may adopt an iftar offering, social services, and conferences ${ }^{17}$ as an instrument to gain visibility, whereas in the case of Shi'as, no motivation works better than Muharram and Șafar ceremonies to go public.

Thanks to Ashura, when Shi'as stand out from a homogeneous and faceless Islam in Italy, they interact with their context or even impart lessons to it. To answer why it was important to commemorate Ashura in public, a middle aged woman of Karachi answered: "Italians have everything but they are empty, we have to offer them something to fill their emptiness". Meanwhile, an Iranian girl collaborating with the students' campaign in her black chador replied: "Italian TV shows many actors with lavish life styles and people get engaged with them, making them their role models. Those are empty models, whereas Imam Husayn is an excellent example of humanity and magnanimity. Our a'immah (Imams) were good examples for humanity. We should present these models to people".

The context of migration educes the creativity necessary to save one's self, and simultaneously dialogue with "others" (Cruz 2008, p. 62). The Lebanese director of the Como Assirat Association remembered that he had organised a play on Imam Husayn one year in the presence of a municipality council member. After the play, he took the opportunity to speak about two Christians among Imam Husayn's companions. He added: “To fight against the devil, you do not have to be a Muslim. Imam Husayn at the time had two servants ... both were Christians and had sacrificed their lives. But why? Because for them the cause of Imam Husayn was the right one. There was good against evil, so they put themselves on the side of the good". The interviewees sometimes admitted that the similarities between Shi'ism and Catholicism in Italy helped them feel more at home. For instance, a Pakistani woman pointed out that, during Passover, Italians used beasts in the procession and wept for Jesus Christ.

Italian converts, however, did not share the migrants' approach towards this issue. Their abstinence from partaking in processions illuminates how the relationship between Shi'as and Ashura in the context of migration depends on social status. The Italian converts deemed these processions useless, and even brutal, in the public arena. They thought that the demotic ritual language would create only awkwardness and embarrassment in the public eye without eliciting any interest from outsiders. This is why they preferred to organise their mourning sessions indoors, by limiting their public presence to current and universally shared causes that regarded all Muslims, such as the Quds Day and manifestations for the war in Iraq, Syria, Lebanon and Gaza, rather than markedly Shi'a issues like Ashura. When the administrator of the Imam Mahdi Centre of Rome, an Italian convert to Shi'ism, was asked about their absence from the processions, he criticised the immigrants' approach to the issue, adding: "If we want to do it only for identity, for self-affirmation ... I understand it because 364 days one feels to be a minority and they are here and ... how to say it ... they are also oppressed ... and one day when they come out, they say 'Look! We Pakistanis, we Iranians, we Lebanese ... we want to show how we behave in our country ... we do so and so' ... I can understand it but I think the right way to do it is to understand the culture and where we are and then understand who Imam Husayn was and what happened in Karbala, what his goal was, what the role of his sister Hadrat Zaynab was ... so we have to organise it well". An unmentioned but obvious reason for these converts' abstinence is that they have far better channels to display their capabilities, namely through linguistic competence and their familiarity with the cultural context; this eases their relationship with it, as well as the simple

give access to the worship hall. For instance, a Shi'a centre of Rome that belongs to the Iranian embassy refused to open its doors to me during the Muharram rituals.

17 For instance, see how Islamic communities of Turin got involved in waste paper collection thanks to Brahim Baya, the spokesman of the Associazione Islamica delle Alpi. See (Eccodallecitta 2019). See the activities of the PSM (Associazione Partecipazione e spritualità musulmana) in (Pepicelli 2018, pp. 108-11). 
yet essential fact that they are not alien to Italy ${ }^{18}$. First-generation immigrants, on the other hand, are either intimidated without or without Italian citizenship, or incapable of speaking Italian.

Having a public voice is a double-edged sword. A veiled woman, a dark-skinned man with a beard, and shalwar qamid represent an indifferent "other". However, when this fragile otherness that normally does not have or is not supposed to have any heterogeneity notices a different voice in itself, it tends to deny its existence or expulse it as an unwanted inaccuracy. Sectarian disputes arise only when Shi'as cling to the linchpin of their public identity-Ashura-and does so no matter how much the official voice of Shi'ism denies accusations of fabricating a sectarian self ${ }^{19}$. During the aforementioned campaign, I faced various negative reactions from Sunni Muslims. In Milan, while I was explaining to a Salvadoran man who had got off his bicycle to observe the procession and was extremely interested in finding out something about it, an Algerian man kept interrupting me, saying to him: "Do not listen to her ... they are all liars ... they are neither Muslim nor Christian ... no one knows who they are and what they want". In Brescia, alongside the procession of Ali Asghar and while I was explaining the Battle of Karbala to an Italian woman, a man I presumed to be her husband intervened, and asked me if harming the body was forbidden in Islam, why those people were beating themselves. The man later turned out to be an Albanian Sunni Muslim who was familiar with the ritual, and who knew about this vulnerability of Shi' as yet posed that rhetorical question to embarrass me in front of an outsider. The Italian secular state, which allows registered associations to have peaceful manifestations, provides a great ease for Shi'as in this case. Javad, who had obtained his master degree in Malesia before coming to Italy for his $\mathrm{PhD}$, spoke about the impossibility of having a campaign like the one that he had launched in Malesia. He said: "It was quite different there because we were dealing with Sunnis and not with Christians. They had more information than Europeans and this made our activity difficult, and maybe you cannot do such works there, but in Italy it's different". He then explained that, in Malesia, there were three main religions and the political order preferred to show the unity and strength of Muslims to others. Therefore, Shi'as could express themselves only in terms of brotherhood and unity with Sunnis. Javad said that, in Italy, they also preferred not to talk to Sunnis. He emphasised: "A non-Muslim has a fresh mind and wants to learn, whereas Sunnis already have their own ideas and try to impose them on us, so we try to avoid Sunnis". In his campaign and during the days leading up to Ashura, we were repeatedly requested to avoid Sunnis through the Telegram group created to prepare students who wanted to contribute to the movement, and, if any encounter occurred, to avoid discussions in a polite manner or limit ourselves to short chats.

\subsection{A Challenge to Political Hierarchy}

One of the entailments of Ashura in Italy is the attenuation, or even abolition, of socio-political hierarchies. The Iranian console, albeit avoiding an outdoor presence, stayed in the line of mourners inside the Imam Ali Centre of Milan and beat his chest alongside simple workers and refugees that sometimes were illiterate and performed menial labour. They sat down beside the same sufrah (table cloth) and were offered the same nadhri (votive food). It was the same for well-known Pakistani and Lebanese preachers, who were brought to Italy from other parts of the world during Muharram and Șafar. In a country where different mosques and husayniyahs are available, politically and religiously important figures do not mix with normal citizens as they opt for specific places of worship or have particular posts in the same hall. However, when such a possibility does not exist, as is the case of

18 Migrants may adopt sex, age and class patterns of the host society but remain "aliens" to it, after all. See (Richardson 1967, pp. 12-13).

19 The inauguration ceremony of the first hawzah of Italy, held on 8 December 2018 in Carpi, offered an ecumenical moment to hear the official voice of Shi'ism of Europe. Given the opening of a markedly Shi'a school in Italy, fifteen clerics who had come from Shi'a centres in Norway, Greece, Spain, France, Austria, Denmark, Germany, Italy, Britain and Sweden took the opportunity to declare unanimously their distances from any attempt to provoke sectarianism. It is worth mentioning that such attempts are always made by Shi'as who have constantly had to deal with the accusations levelled at them by the representatives of mainstream Islam. 
Italy, the usual hierarchies disintegrate while religious bonds gain momentum. The situation propels Shi'as towards a state of primitive and non-institutionalised religion, which happens to European Muslims in general (Allievi 2002, p. 23), but seems awkward in the case of the Iranian diplomats since the theocratic system tends to exalt politicians.

\section{Discussion and Conclusions}

Four outcomes of the interaction between Italy, as the host context, and the so-called pillar of the Shi'a identity, or Ashura and rituals that revolve around it, were analysed. These rituals in Italy provide Shi'as with a series of both opportunities and challenges that work as catalysts of change. Firstly, since Shi'ism in Italy (like Islam in general) is multi-ethnic, in ecumenical moments, the ethnic peculiarities cannot but surface. The Italian public sphere had become a stage for confrontation between two antithetical methods of commemorating the Karbala tragedy. The first adapted Ashura to the demands of the host society, sacrificing symbolic elements of the message in favour of verbal ones. The second and more traditional method remained attached to its conventional instruments partly to compensate for its usual lack of visibility. Further, it seemed that the available gender paradigms in Italy had exerted a limited impact on Shi'a rituals. The most visible trace of this influence was noticeable among Afghans. The Pakistani women's behaviour in public, although exceeding the limits established by ayatollahs, presented nothing more than what the Pakistani folk Shi'ism envisaged for women and their roles in such occasions. The Afghan women, however, enjoyed the privilege of leading the ritual only thanks to concessions from their male counterparts. Middle Eastern Shi'as presented the same pattern of gender apartheid that governs their worship halls in normal periods ${ }^{20}$ without any evolution in gender roles. Thirdly, Ashura offered the usually invisible Shi'as a good opportunity to compensate for their normal absence from the public arena. The Italian secular state, within certain limits, allowed Shi'as to go public, but this occasion, despite its opportunities, provoked sectarian attacks against Shi'as. Lastly, the lack of Shi'a mosques and husayniyahs in Italy posed a challenge to community hierarchies.

Apart from Italy's contributions to this trend, there was also an unwanted but important impetus for change. The rise of Sunni extremism unexpectedly benefited Iranian students as they managed to define themselves as counterexamples to terrorism. In Iran's contemporary history, Ashura was exploited as a catalyst for political mobilisation in difficult moments of revolution and war. In those moments, Imam Husayn became a paradigm of a just man employed to denounce his counterexamples who was once Shah and then Saddam Husayn (Shirazi 2005, p. 94; Hegland 2005, pp. 199-201; Chelkowski and Dabashi 2000, pp. 70-80). In Italy, Justice is not what the Umayyads deprived the third Imam of, but European peace jeopardised by Sunni extremism. This new signified of justice offered the young Shi'as a common terrain to engage with a relatively hostile context ${ }^{21}$. In Rome, the absence of procession and what could capture the public's attention (like what occurred in Brescia and Milan) led Iranian students to be creative and link their campaign to the International Day of Peace. The desire to be perceived as messengers of peace inevitably distanced students from the traditional ritual symbols that evoke battlefields, soldiers, and bloodshed. On the day of Ashura, students in different European cities were given white shawls and were asked to preferably avoid black clothing. Thereby, zanjir (a chain blade whip) and means of auto-flagellation were replaced by pamphlets, flowers and water bottles. It was understood that histrionic expression methods in Italy would raise the chances of sectarian attacks against Shi'as, whereas the need for universal credibility

20 See a comparison between doctrinal stances and what occurs in a Middle Eastern hall in Turin in terms of gender division and women's activates in (Mirshahvalad 2017).

21 The «repositioning of self and other», categorising Islamic extremism into other is a stratagem for forging an alliance between Shi' ism and Europe perceived as self. It is an example of what Flaskerud called 'street theology'. See (Flaskerud 2018). 
was met with rational and sober behaviour ${ }^{22}$. It is why Iranian students in Europe made use of an ideologised Shi'ism voice, like the one bolstered by such intellectuals as Muțahari2 ${ }^{23}$. Shi'as' status in Europe propelled the Iranian students to employ a more socially engaged version of Shi'ism to the detriment of its traditional, emotionally escalating form to confront a much more powerful reality: European culture.

The need for survival in a foreign context is another catalyst of change that separates Italian converts from immigrants. The latter have to find strategies for self-satisfaction ${ }^{24}$. One of these strategies, which functions more effectively than economic factors, is to assimilate into the host society (Angelini et al. 2015). This satisfaction improves the immigrants' life experience and is a key factor in their psychological adaptation to the receiving society (Berry and Sam 1997, p. 302). The politics of assimilation do not exist for Italian converts, not only because they do not need them, but also because their approach to Shi'ism repels the Catholicism that immigrants strive to present as similar to themselves. Many of the Shi'a-born interviewees tended to see similarities between Shi'ism and certain religious elements of the host society. Some of them recognized the presence of Christians among Ashura protagonists or the medieval mourners of Imam Husayn. Such «poetics of similarity» exist among Greek Shi'as as well (Chatziprokopiou and Hatziprokopiou 2017). In contrast, a highly religious Iranian woman married to a converted Italian criticised this approach because, in her view, what had always attracted Italians to Shi'ism consisted exactly in its otherness. She believed that offering a Christianised version of Shi'ism would prevent further conversions. Her observation, supported by her abhorrence for cultural relativism, was validated by the Italian converts: if Husayn's tragedy is incomprehensible for non-Shi'as, the right strategy to face it is to limit its commemoration to indoor venues, restricting public demonstrations to universally shared and contemporary causes like those of the Palestinians and Kobanis. In other words, being public for a Sunni common cause is preferable to being a vulnerable Shi'a cloaked in Catholicism.

Returning to Rappaport's theory and our initial question, what happens to these rituals in Italy does not only consist of the emergence of new presentation patterns, new languages and physical gestures, but also the birth of a new concept of justice. This new definition of justice is traceable in how Iranian students narrate the martyrdom of Imam Husayn to outsiders, and also in the new communal order in terms of gender and power hierarchy, inasmuch as any social order inherently includes justice. The difference, however, is that the Iranian students choose their message with awareness, and consequently its conveyance changes. Other subjects have not opted for it wittingly (women, Shi'a authorities and traditional Shi'as), despite undergoing a certain level of change. Students manipulate the form and hence the content of their message, while other subjects experience some level of change because in Italy there are not enough suitable spaces for rituals, there is not enough equipment for mourning, Shi'as are not allowed to commit bloody self-flagellation, and they have to observe the time and space conceded to them by municipalities. Italian converts see no sense in identifying their third Imam with Jesus Christ (the issue explicitly underlined in the students' booklet), but neither do they see any sense in commemorating such an episode in public. Therefore, students present the highest level of change in their performance, since the desire for integration propels them towards strategies like conceptualisation of a non-discursive, affective and ineffable subject to make it more comprehensible for outsiders, and finding measures to reduce the distance between "us" and "them" 25 . The process

22 As Rodolf Otto has observed, the use of irrational behaviour reduces the universality of a religion. See (Tullio-Altan and Massenzio 1998, p. 28).

23 It is said that "religion is turned into ideology when an elite is in a situation that prevents it from using traditional religion which is regarded as inappropriate to the new realities" (Rachik 2009, p. 350).

24 When migrants join a certain level of satisfaction, they try to identify themselves with the host society. See (Richardson 1967, pp. 3-30).

25 It is interesting to see that the more familiarity of the host context with Shi'as and their rituals, such as what one witnesses in the U.K., has not exempted Shi' as from almost the same intergenerational controversies (Spellman-Poots 2012, p. 44), even though one expects less disharmony where Shi'as have had a longer presence and thus have developed strong ties with the new context (see note 6). 
of conceptualising a symbol inevitably ushers in a simplification of its content first, and second a dedramatisation of its reality. The whole Ashura epic in Italy, with its antagonists and protagonists, needed to be reduced to one single idea: justice. Students were explicitly requested to present the notion of justice and to not mention anyone but Husayn. Details, dates and names were considered redundant and confusing. The tragedy was remoulded to fit the exigencies of the new context. Young Shi'as were attempting to develop empathy between themselves and outsiders through a universal but vague value, one widely acceptable regardless of faith, nationality or gender. Theoretically, the memory of the Battle of 680 is a centuries-long leitmotif that connects the Shi'as' past and present, and operates as their identity source. However, as seen in this article, adapting its commemorative rituals to the Italian context alongside the inevitable shifts in form and language-which also imply a significant change in ritual content-has aroused doubts over the continuity of this presumed constant.

Funding: This research was supported by a doctoral fellowship of the University of Turin.

Conflicts of Interest: The funder had no role in the design of the study; in the collection, analyses, or interpretation of data; in the writing of the manuscript, or in the decision to publish the results.

\section{References}

Abusharaf, Rogaia Mustafa. 1998. Structural Adaptations in an Immigrant Muslim Congregation in New York. In Gathering in Diaspora: Religious Communities and the New Immigration. Edited by R. Stephan Warner and Judith G. Wittner. Philadelphia: Temple University Press, pp. 235-61.

Alibhai, Fayaz S. 2018. Twelver Shia in Edinburgh: Making Muharram, mourning Husayn. Contemporary Islam, 1-24. [CrossRef]

Allievi, Stefano. 2002. Musulmani d'Occidente: Tendenze dell'Islam Europeo. Rome: Carocci.

Allievi, Stefano. 2003. Islam Italiano: Viaggio Nella Seconda Religione del Paese. Turin: Einaudi.

Aluffi Beck-Peccoz, Roberta. 2004. The Legal Treatment of the Muslim Minority in Italy. In The Legal Treatment of Islamic Minorities in Europe. Edited by Roberta Aluffi Beck-Peccoz and Giovanna Zincone. Leuven: Peeters, pp. 133-58.

Angelini, Viola, Laura Casi, and Luca Corazzini. 2015. Life Satisfaction of Immigrants: Does Cultural Assimilation Matters? Journal of Population Economics 28: 817-44. [CrossRef]

Ayoub, Mahmoud A. 1978. Redemptive Suffering in Islam. Hague: Mouton.

Berry, John W., and David L. Sam. 1997. Acculturation and Adaptation. In Handbook of Cross-Cultural Psychology: Social Behavior and Applications. Edited by John W. Berry, Marshall H. Segall and Cigdem Kagitcibasi. Needham Heights: Viacom Company, vol. 3, pp. 291-326.

Bøe, Marianne, and Ingvild Flaskerud. 2017. A Minority in the Making: The Shia Muslim Community in Norway. Journal of Muslims in Europe 6: 179-97. [CrossRef]

Bombardieri, Maria. 2011. Sale Sciite. In Moschee D'italia: Il Diritto al Luogo di Culto, il Dibattito Sociale e Politico. Bologna: EMI, pp. 199-201.

Chatziprokopiou, Marios, and Panos Hatziprokopiou. 2017. Between the Politics of Difference and the Poetics of Similarity: Performing Ashura in Piraeus. Journal of Muslims in Europe 6: 198-215. [CrossRef]

Chelkowski, Peter J. 2005. Iconography of the Women of Karbala: Tiles, Murals, Stamps, and Posters. In The Women of Karbala: Ritual Performance and Symbolic Discourses in Modern Shi'i Islam. Edited by Kamran Scot Aghaie. Austin: University of Texas Press, pp. 119-38.

Chelkowski, Peter J., and Hamid Dabashi. 2000. Staging Revolution: The Art of Persuasion in the Islamic Republic of Ira. London: Booth-Cibborn.

Coppi, Andrea, and Andrea Spreafico. 2006. La Rappresentanza dei Musulmani in Italia. Rome: XL.

Cruz, Gemma Tulud. 2008. Singing the Lord's Song in a Strange Land: Religious Identity in the Context of Migration. In Migration: Challenge to Religious Identity. Luzern: Forum Mission, pp. 60-87.

Eccodallecitta. 2019. Available online: http://www.ecodallecitta.it/notizie/380901/cartoniadi-brahim-bayasecondo-lislam-siamo-i-custodi-della-terra/ (accessed on 2 January 2019).

Flaskerud, Ingvild. 2018. 'Street Theology': Vernacular Theology and Muslim Youth in Norway. Islam and Christian-Muslim Relations 29: 485-507. [CrossRef]

Guolo, Renzo. 2010. Identità e Paura: Gli Italiani e l'immigrazione. Udine: Forum. 
Hegland, Mary Elaine. 2005. Women of Karbala Moving to America: Shi'i Rituals in Iran, Pakistan, and California. In The Women of Karbala: Ritual Performance and Symbolic Discourses in Modern Shi'i Islam. Edited by Kamran Scot Aghaie. Austin: University of Texas Press, pp. 199-227.

Introvigne, Massimo, and Pierluigi Zoccatelli. 2006. Le Religioni in Italia. Turin: Elledici.

Langer, Robert, and Benjamin Weineck. 2017. Shiite "Communities of Practice" in Germany: Researching Multi-Local, Heterogeneous Actors in Transnational Space. Journal of Muslims in Europe 6: 216-40. [CrossRef] Lano, Angela. 2005. Islam d'Italia: Inchiesta su una Realtà in Crescita. Milan: Paoline.

Lanternari, Vittorio. 1997. Antropologia Religiosa: Etnologia, Storia e Folklore. Bari: Dedaldo.

Mach, Zdzislaw. 1993. Symbols. In Conflict, and Identity: Essays in Political Anthropology. Albany: State University of New York.

Mazzacane, Lello. 1985. Struttura di Festa: Forma, Struttura e Modello Delle Feste Religiose Meridionali. Milan: F. Angeli.

Menegotto, Andrea. 2004. Sciiti in Italia. In Dialogo al-Hiwar. Torino: Centro F. Peirone, vol. 3.

Mirshahvalad, Minoo. 2017. Women in an Italian Shi'a Worship Hall. Genesis, Rivista della Società Italiana delle Storiche 16: 83-99.

Mirshahvalad, Minoo. 2018. How an Italian Amorphous Space Became a Twelver Shi'a Mosque. Mediterranean Knowledge, Working Papers Series 5: 105-28.

Park, Robert E., and Ernest W. Burgess. 1970. Introduction to the Science of Sociology (Student Edition). Chicago and London: The University of Chicago Press.

Pepicelli, Renata. 2018. Spritualità, Politica e Pensiero Islamico in Italia. I Giovani e l'Eredità dell'Islamismo Magrebino tra Continuità e Innovazione. In Transnazionalismo e Cittadinanza. Edited by Renata Pepicelli and Ivana Acocella. Bologna: Mulino, pp. 105-39.

Pin, Andrea. 2010. Laicità e Islam Nell'ordinamento Italiano: Una Questione di Metodo. Milan: CEDAM.

Rachik, Hassan. 2009. How Religion Turns Into Ideology. The Journal of North African Studies 14: 347-58. [CrossRef] Rappaport, Roy A. 1999. Ritual and Religion in the Making of Humanity. Cambridge: Cambridge University Press.

Redfield, Robert, Linton Ralph, and Herskovits Melville. 1936. Memorandum for the Study of Acculturation. American Anthropologist 38: 149-52. [CrossRef]

Richardson, Alan. 1967. A Theory and Method for the Psychological Study of Assimilation. The International Migration Review 2: 3-30. [CrossRef]

Sachedina, Abdulaziz. 1991. A Minority within a Minority: The Case of the Shi'a in North America. In Muslim Communities in North America. Edited by Yvonne Yazbeck Haddad and Jane I. Smith. Albany: State University of New York Press, pp. 3-14.

Sam, David L. 2006. Acculturation: Conceptual background and core components. In The Cambridge Handbook of Acculturation Psychology. Edited by David L. Sam and John W. Berry. Cambridge: Cambridge University Press, pp. 11-26.

Scharbrodt, Oliver. 2018. A Minority within a Minority?: The Complexity and Multilocality of Transnational Twelver Shia Networks in Britain. Contemporary Islam 1-19. [CrossRef]

Sciiti in Italia. 2012. Il puro Islam. Napels: Associazione Islamica Ahl al-Bayt, vol. 18, p. 17.

Shirazi, Faegheh. 2005. The Daughters of Karbala: Images of Women in Popular Shi'i Culture in Iran. In The Women of Karbala: Ritual Performance and Symbolic Discourses in Modern Shi'i Islam. Edited by Kamran Scot Aghaie. Austin: University of Texas Press, pp. 93-118.

Spellman-Poots, Kathryn. 2012. Manifestations of Ashura among Young British Shi'is. In Ethnographies of Islam: Ritual Performances and Everyday Practices. Edited by Baudouin Duret, Thomas Pierret, Paulo G. Pinto and Kathryn Spellman-Poots. Edinburg: Edinburg University Press, pp. 40-49.

Tullio-Altan, Carlo, and Marcello Massenzio. 1998. Religioni, Simboli, Società. Milan: Feltrinelli.

Vanzan, Anna. 2004. Gruppi Sciiti in Italia e Connessioni con le Reti Sciite Transnazionali. Paper presented at the Conference of L'islam, Turin, Italia, December 2-3. Its English translation is available in Muraqqa'e Sharqi. Edited by Rastegar Anna Vanzan and Soussie. San Marino: AIEP, 2007, pp. 201-12.

(C) 2019 by the author. Licensee MDPI, Basel, Switzerland. This article is an open access article distributed under the terms and conditions of the Creative Commons Attribution (CC BY) license (http:// creativecommons.org/licenses/by/4.0/). 